\title{
Erratum to: Responses of Uniola paniculata L. (Poaceae), an Essential Dune-Building Grass, to Complex Changing Environmental Gradients on the Coastal Dunes
}

\author{
Cara L. Gormally • Lisa A. Donovan
}

Published online: 10 April 2010

(C) Coastal and Estuarine Research Federation 2010

Erratum to: Estuaries and Coasts

DOI: $10.1007 / \mathbf{s} 12237-010-9269-2$

The units for aboveground tissue nutrient concentrations were measured in $\mathrm{mg} / \mathrm{g}$, not $\mathrm{mg} / \mathrm{kg}$, as shown in the original figure. The y-axis label was missing for the bottom right graph, and should be "Soil K (mg/kg)."

The corrected figure is as follows:

The online version of the original article can be found at http://dx.doi. org/10.1007/s12237-010-9269-2.

C. L. Gormally $(\bowtie) \cdot$ L. A. Donovan

Department of Plant Biology, University of Georgia,

2507 Miller Plant Sciences,

Athens, GA 30602, USA

e-mail: cgormally@plantbio.uga.edu 
Fig. 2 Uniola paniculata tissue nutrient concentrations which varied significantly with distance from shoreline, shown with corresponding soil nutrient concentrations (Summer 2006 study). LS means \pm 1 standard error are presented. Different letters indicate significantly different means
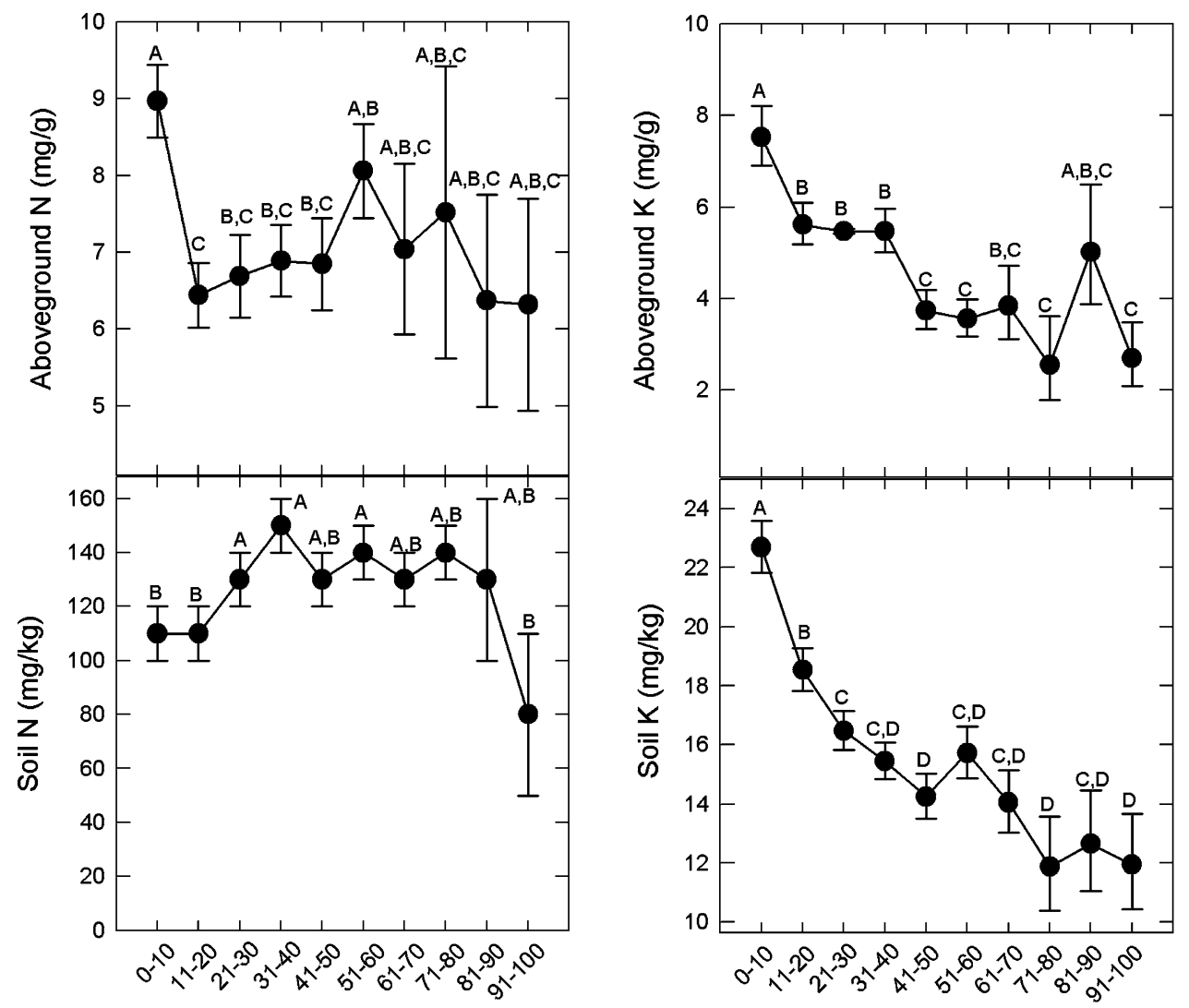

Distance from shoreline (10 $\mathrm{m}$ intervals) 